\title{
TGTDCL Prepaid Domestic Gas Metering System \& Reduction of System Loss in the Energy Sector of Bangladesh
}

Nargis ( $\nabla$ nargis.suma1@gmail.com )

Akter

\section{Research Article}

Keywords: Natural Gas, Metering, Pre-paid, Domestic Consumption, Wastage

Posted Date: December 30th, 2021

DOI: https://doi.org/10.21203/rs.3.rs-793142/v2

License: (c) (i) This work is licensed under a Creative Commons Attribution 4.0 International License. Read Full License 


\section{Abstract}

Titas Gas Transmission and Distribution Company Limited (TGTDCL) is the largest gas transmission and distribution company in Bangladesh. The company undertook a pilot project in July 2005 to implement pre-paid metering on a limited scale. The outcomes of the pilot project are analyzed and presented in this paper. Most of the customers under the project appear to be indifferent to the new system. The revenue of TGTDCL was less compared to the same number of un-metered customers. The pilot project has a lack of design, planning, and implementation errors. Calculations are therefore made based on the assumed parameters. Clear and conclusive results regarding the reduction of gas wastage and financial benefits are hard to determine.

\section{Introduction}

There are many gas transmission and distribution companies in Bangladesh, one of the major ones is Titas Gas Transmission and Distribution Company Limited (TGDTCL). TGDTCL was formed in 1964, commencing operations commercially in 1978 through supplying gas connections domestically in the capital city of Bangladesh. To date, they have branched out, franchising in different areas to stay competitive for their customers. The customer range is diverse, whether industrial or commercial or independent or non-independent power producers to fertilizer and others. TGDTCL purchases its gas from the local Bangladeshi government organization, known as PETROBANGLA. Domestic or local customers have no metering system. There were about

1.3 million domestic household connections in mid-June of 2014 , of which users consume $13 \%$ of the total gas sales. Domestic consumers waste a lot of gas from previous studies, and there are gas inefficiencies in the Dhaka metropolitan area. The company is listed in the stock market and possess strong board of governance. (Ahmed, 2021).

Due to the introduction of prepaid meter system, the advantage of advanced gas billing has raised awareness on the wastage and misuse of gas. Though a disadvantage to the new system, customers who have bad intentions and are dishonest tamper with the meter don't care for ethics and gas wastage. With both the advantage and disadvantages in mind, the former outweighing the latter, domestic customers must have such a system. Therefore, TGDTCL has chosen to take on this project of the prepaid gas metering system for its national customers considering it will have more advantages and a good impact to counteract gas wastage by reducing system loss and wastage and help in the conservation of energy. Currently, there have been around 2,00,000. prepaid gas meters in use around the gas regulating areas.

\section{Problem Indentification}

Titas has a vast customer base for their different franchises. Customers have a fixed monthly gas bill. Wastage and misuse of gas is a significant issue in Bangladesh. The monthly gas bill is BDT 450 for double burners, but the customers can use any quantity they prefer. Research shows customers use 99 cubic meters per month without the meter. Prepaid meters help acquire fees for gas before usage. If prepaid meters are installed, the consumers will have to pay for each volume of gas they consume. It will raise more awareness against wastage and misuse of gas. It will also decrease the use of unauthorized gas appliances. It also helps to better customer services, open a communication link, and reduce outstanding dues.

From the research, we want to investigate the following questions:

(a) Does the projected decrease systemic loss and wastage and raise awareness of gas usage inefficiency?

(b) Is the theoretical transmission loss is greater than the actual transmission loss?

Bangladesh has many natural resources. One limitation but significant is natural gas. Bangladesh, like a third-world country, needs to use this limited natural resource efficiently. Efficient and effective use of such resources like that of natural gases brings in foreign direct investments (FDIs), which then help develop the country. Pipeline gasses used for domestic purposes can be seen as a loss of natural resources. Customer management with the traditional system was chaotic. From collecting bills to the correct bookkeeping with the alliance of different banks, customer vigilance can be very lengthy and time-consuming. This prepaid meter system cuts down the time and travel hassle. Overall, this research will help the company reduce the systemic loss and customer improvement in terms of natural gasses and their wastage.

Page 2/13 


\section{Prepaid Meter Installation}

Under the Natural Gas Efficiency Project (BD-P78) included in the 35th ODA Loan Package of the Government of Japan, a project titled "Installation of Prepaid Gas Meter for TGTDCL" is being implemented with funding from JICA, GB and TGTDCL. Dhanmondi, Mahammadpur, Sher-e-Bangla Nagar, Mirpur, Kafrul, Cantonment, Khilkhet, Gulshan, Banani, Baridhara, Bashundhara, Bimanbandar, Uttara, Uttarakhand, Dakshin Khan, Baja, Rampura, Tejgaon, Khilgaon and Mofiz in Dhaka city. The installation of paid gas meters is in phases. The estimated cost of the project is BDT 498.94 crore (JICA BDT 440.8 crore, GOB BDT 57.92 crore and own funding BDT 1.34 crore) as per RDPP (1st Amendment) and period from January 2015 to December until 2020.

The project's main objectives are to use affordable, efficient, safe, and sustainable fuels and reduce system losses, modern customer-friendly management and above all, gas-saving and improve the quality of customer service. It is to be noted that the use of prepaid meters has increased consumer awareness and the possibility of saving gas at the residential level by reducing the wastage of natural gas. Prepaid meters are imported from overseas country so fluctuations in exchange rate and inflation can have impact on this economic growth factors. (Khan, 2021 and Salma, 2021).

The agreement was signed with Pegasus International (UK) Ltd., a foreign consulting firm, on October 08, 2015, and the consultants joined on October 19, 2015. On March 16, 2017, TGTDCL and ToycKeiki Co. Ltd., Japan- Engineering, Procurement \& Construction (EPC) Agreement was signed and the agreement came into effect on March 202018 after the approval of Jaibar. The installation of meters in the customer's yard started from September 16, 2018. As of June 30, 2020, 200000 prepaid gas meters in the home yard has been installed.

Construction of a separate Data Center Gas Disaster Recovery Center has been completed under the project. POS has already been introduced in various areas under a separate agreement with United Commercial Bank (UCB) Limited to manage the Point of Sales (POS). Customers can easily dispense prepaid cards.

Note that according to ABDRP for FY 2019-20, the amount in favor of the project is BDT 86.45 crore against BDT 86.02 have been spent, which means that in the financial year 2019-20, the financial priority will be $99.50 \%$ against the back of the year. The actual progress of the project is about 95\%. Prepaid meters were introduced in June,2018. No metering keeps Titas in the dark as proper calculation cannot be identified.

\section{System Loss}

Efforts have been commenced to lessen this system loss within the country. The superior teams have reviewed the properties of the Industrial \& severed customers. Special efforts put in by Titas management under the direction of the Board, PETROBANGLA and Ministry of Bangladesh, the financial analysis shows that optimistic results could be achieved from February-06 and system loss could decrease to $5.26 \%$ during the year. And so, it has come down to $5.26 \%$ compared to $6.47 \%$ in the preceding year. Further steps have been taken to bring the loss down to an additional $2 \%$ less this year.

\section{Literature Review}

Natural gas is Hydrocarbons that are located in gas or vapor at normal pressure and heat. Natural gas contains methane and ethane, propane, and even conventional wastes, including Nitrogen, Carbon dioxide, and Hydrogen Sulfide. In the 19th century, natural gas would have been lifted as a by-product of producing oil. So, this unnecessary natural gas was a distribution problem in the active oil fields. In other words, we can say that the market was essential for natural gas surrounding the wellhead; otherwise it was simply valueless. In the early 20thcentury, that unnecessary by-product of producing oil generally burned at oil fields.

There are inevitable losses in transportation and distribution of gas. It depends on many factors, manners and types of transport. It also depends on the quality of transport systems, gaseous fuel quality, the quality of metering devices and adjustments. In the article, the focus is on natural gas characteristics. It reviews the consumption and production of gas and the 
losses in transportation and distribution of natural gas for the region of Serbia. Natural loss reduction effects are analyzed from the example of one distributor after the implementation of appropriate measures. (Adamovic,2015)

Gas must be utilized properly and wisely as there is a lot of energy crisis. The prepaid gas metering system is designed as a smart card, and it is nicely presented in this paper. By using prepaid gas metering system, consumers will be more conscious about utilizing gas properly. As a result, a more promising, more accessible, faster and accurate billing scheme will be developed. The system is designed with state-of-the-art digital and information technology. The system is developed and tested with a prototype. (Khan, 2010). The investment and capital mobility also affects the meter replacement process. The process is capital intensive and relies heavily on labor availability framework. (Mohammad \& Mohammad, 2010). The changes in unemployment rates and public investments can also affect energy investments and relevant works. 12. Mahmoudi, (2021), Alam, et. al., (2013), Alam, (2021) tries to find the impact of factors of productions on energy investment and consumptions. The prepaid meter installment is environment friendly and has sustainable long-term effect on economy. (Alam, 2021 and Alam, \& Hossain, (2018).

It is almost impossible to completely avoid transmission loss during natural gas transportation because there is a limitation in accuracy and measurement. Even there is uncertainty in measuring the prepaid meter instruments installed in gas pipeline systems. This study established an uncertainty model that will measure the complex flow rates of trunk gas pipelines. Calculation method of various metering systems has been analyzed. A calculation method which will determine the theoretical transmission loss has been developed. Theoretical loss is an early warning regarding transmission loss. (Mai, 2019). If the theoretical transmission loss is greater than the actual transmission loss, then it is clear that the pipeline metering system is working properly. If it is vice versa, then there should be investigation to determine why the loss happening and correspondent measures should be taken. Pramanik, \& Polansky, (2020), Pramanik, (2020), Pramanik, \& Polansky, (2021) and Pramanik, (2021) tries to figure out the optimum policies for transmission framework using the path integral process. Through this the relevant factors can be optimized to reach and efficient solution.

Across the world, in the developed countries billing and metering system for utilities such as electricity, gas and water has been widely studied and being implemented. But the scenario is different in Pakistan as technology is still on its way to be implemented for industrial as well as domestic consumers. A prepaid metering system has been designed to lowering gas consumption. For high gas consumption, which is the industrial consumers, the gas meter is wirelessly connected with the billing office. It is called the metered billing system and gas consumption unit can be easily read. (Khan,2003). The dynamics of population migration also affects the changes in the gas meter replacement system. Minar (2018), Minar (2019) and Minar \& Abdul (2020) found that Rohingya migration can have significant effect on the gas transmission and necessary utility services. The security risk is quite high in that area and unstable political connections affect the policies.

\section{Methodology And Research Design}

\section{Methods of collecting data/Sampling method}

For survey purposes many methods were used such as a questionnaire was developed along with an interview which was used to gather clear understanding and a deeper insight into the conversation of the topic. Both qualitative and quantitative methods were used. The questionnaire used in this study is given in the Appendix B. The questionnaire survey was implemented for collecting first hand, primary data from the project area. Before filling the questionnaire, the general idea of the research objectives was addressed to the population sample chosen. After that, the questionnaire was distributed, and participants were requested to fill the questionnaire based on the real-life experience they had regarding the pre-paid metering system. Both open end and close end questions were set in the questionnaire to reveal the real perception of the respondents.

\section{Selection of Study Area}


Keeping the matter of having a time constraint in mind and for convenience purposes for the collection of data in the questionnaire, participants have provided data feedback through e-mail. Along with that, some of the data for questionnaire was were collected from the Office.

\section{Sample Size}

Respondents were categorized as:

1. TGTDCL company employees,

2. Personnel who are dealing with the pre-paid projects

3. Existing customers who are using these types of meters

\section{Data processing and Analysis/Analytical Framework}

Data collected had to be processed through cleaning, editing, arranging before statistical analysis could be conducted. The statistical analytical tool used was Statistical Package for Social Science (SPSS) which is used to analyze and interpret the subject matter. Along with that, Microsoft Excel has been used for preparing the data tables\& other tables.

\section{System loss Reduction Programme:}

a) System loss is a major issue and so TGTDCL has been executing a rather different action plan to combat the issue of system loss or areas for unaccounted gas in terms of input and output, repairing and fixing responsibilities, along with sealing RMS, the calibration and exchange of the old meters, extreme attentiveness, disconnecting of unauthorized connections by the operational force, prompt clearance of court cases, electronic volume corrector, flow/pressure logging device etc. Steps are taken to assure appropriate gas bill for their industrial customers through using a computerized remote-metering system for the meter readings in order to tackle system loss. These measures are taken in the following areas: Narayanganj, Sonargaon Tongi, Narsingdi, Ashuganj and Brahmanbaria and metro sales zone. An orientation program is being put into place by assigning officers in order to collect on these meter readings through recurrent visits to the premises if the customers. These officers are also responsible for Meter sealing and testing programs which have to be completed on effectively on time. In spite of the efforts made by TGTDCL, system loss reduction at a chosen level could not be attained due to scarcity of competent manpower, construction of unlawful by-pass line by the fraudulent customers, sanction order of the Honorable Court in favor of cheating customers, prohibited re-connection from disconnected risers, unsanctioned use of additional appliances, excessive gas consumption by the non-metered domestic clients, meddling on RMS and meter tampering etc.

b) To decrease system loss and to achieve collecting on arrear gas bills as directed by higher authority, TGTDCL designed eight inspection teams and two disconnection teams to examine all the industrial customers' locations to find out if there is unlawful use of gas by deceitful customers.

Table 1: Difference between purchase and sale thus system loss/gain

\begin{tabular}{|lll|}
\hline year & Quantity $(\mathrm{mmcm})$ & percentage \\
\hline $2014-2015$ & 625.62 & 3.90 \\
\hline $2015-2016$ & 479.22 & 2.81 \\
\hline $2016-2017$ & 232.89 & 1.35 \\
\hline $2017-2018$ & 201.19 & 1.17 \\
\hline $2018-2019$ & 1003.83 & 5.71 \\
\hline
\end{tabular}

Page 5/13 
Titas authority has taken steps to reduce system loss. Authority has taken decision to cut off unauthorized gas pipeline and set up mobile court. BERC order \#2018/03 dated on 16-10-2018 to 18-09-2018 to consider Actual Consumption rather than billed Consumption. In that case higher heating value is not included in 2018-2019 financial year gas sales so the gas sale quantity decreased and a significant increase in system loss is seen.

Table 2: Gas Price in Bangladesh

\begin{tabular}{|lll|}
\hline Explanation & Unit & 01 July 2019 (Taka) \\
\hline Electricity & Cubic Meter & 4.45 \\
\hline Fertilizer & $"$ & 4.45 \\
\hline Field Gas for CNG & $"$ & 43 \\
\hline Captive Power & $"$ & 13.85 \\
\hline Industry & $"$ & 10.70 \\
\hline Tea Garden & $"$ & 10.70 \\
\hline Commercial-Hotel \& Restaurant & & 23 \\
\hline Commercial- Small \& Medium Industry & & 17.04 \\
\hline Residential-Meter & $"$ & 12.60 \\
\hline Residential- Non-Meter & One stove & 925 \\
\hline Residential- Non-Meter & Two stoves & 975 \\
\hline
\end{tabular}

Table 3: Customers of TGTDCL in previous five years

\begin{tabular}{|llllll|}
\hline Customer Type & \multicolumn{5}{c|}{ Number of Customers } \\
\cline { 2 - 6 } & $2014-2015$ & $2015-2016$ & $2016-2017$ & $2017-2018$ & $2018-2019$ \\
\hline POWER & 35 & 38 & 43 & 44 & 45 \\
\hline FERTILISER & 3 & 3 & 3 & 3 & 3 \\
\hline INDUSTRIAL & 4590 & 4604 & 4610 & 5128 & 5279 \\
\hline CAPTIVE & 1080 & 1085 & 1088 & 1630 & 1680 \\
\hline CNG & 331 & 333 & 335 & 382 & 394 \\
\hline COMMERCIAL & 10913 & 10917 & 10919 & 11688 & 12075 \\
\hline DOMESTIC & 1880353 & 2006013 & 2717536 & 2764247 & 2846419 \\
\hline
\end{tabular}

Out of all other customers, domestic customers are the targeted area of analyzing the prepaid meters installation.

Table 4: Calculation of System Loss in 2018-2019 


\begin{tabular}{|c|c|c|c|c|c|c|c|}
\hline Month & $\begin{array}{l}\text { Net } \\
\text { Purchase }\end{array}$ & $\begin{array}{l}\text { Sales with } \\
\text { condensate }\end{array}$ & $\begin{array}{l}\text { Total System } \\
\text { Loss }\end{array}$ & $\begin{array}{l}\text { Allowable } \\
\text { System Loss }\end{array}$ & $\begin{array}{l}\text { Net } \\
\text { System Loss }\end{array}$ & $\begin{array}{l}\text { System } \\
\text { Loss In } \\
\%\end{array}$ & $\begin{array}{l}\text { Allowable } \\
\text { System } \\
\text { Loss \% }\end{array}$ \\
\hline Jul-18 & $1,437,094,642$ & $1,381,705,632$ & $55,389,010$ & - & $55,389,010$ & $3.85 \%$ & $0.00 \%$ \\
\hline $\begin{array}{l}\text { Aug- } \\
18\end{array}$ & $1,327,546,861$ & $1,427,890,089$ & $(100,343,228)$ & - & $(100,343,228)$ & $-7.56 \%$ & $0.00 \%$ \\
\hline $\begin{array}{l}\text { Sep- } \\
21\end{array}$ & $1,394,910,064$ & $1,365,095,313$ & $29,814,751$ & $13,382,977$ & $16,431,774$ & 0 & 0 \\
\hline Oct-18 & $1,481,862,326$ & $1,388,879,332$ & $92,982,994$ & $32,843,575$ & $60,139,419$ & $4.06 \%$ & $2.22 \%$ \\
\hline $\begin{array}{l}\text { Nov- } \\
18\end{array}$ & $1,426,311,072$ & $1,383,522,133$ & $42,788,939$ & $31,608,365$ & $11,180,574$ & $0.78 \%$ & $2.22 \%$ \\
\hline $\begin{array}{l}\text { Dec- } \\
18\end{array}$ & $1,471,573,737$ & $1,333,352,234$ & $138,221,503$ & $32,641,542$ & $105,579,961$ & $7.17 \%$ & $2.22 \%$ \\
\hline $\begin{array}{l}\text { Jan- } \\
19\end{array}$ & $1,567,922,200$ & 1,368,884,977 & $199,037,223$ & $34,796,091$ & $164,241,132$ & $10.48 \%$ & $2.22 \%$ \\
\hline $\begin{array}{l}\text { Feb- } \\
19\end{array}$ & $1,364,712,156$ & $1,351,587,152$ & $13,125,004$ & $30,133,850$ & $(17,008,846)$ & $-1.25 \%$ & $2.21 \%$ \\
\hline $\begin{array}{l}\text { Mar- } \\
19\end{array}$ & $1,583,909,157$ & $1,400,549,316$ & $183,359,841$ & $35,177,001$ & $148,182,840$ & $9.36 \%$ & $2.22 \%$ \\
\hline Apr-19 & $1,529,797,853$ & $1,359,993,482$ & $169,804,371$ & $33,967,958$ & $135,836,413$ & $8.88 \%$ & $2.22 \%$ \\
\hline $\begin{array}{l}\text { May- } \\
19\end{array}$ & $1,593,848,760$ & $1,457,915,328$ & $135,933,432$ & $35,414,534$ & $100,518,898$ & $6.31 \%$ & $2.22 \%$ \\
\hline $\begin{array}{l}\text { Jun- } \\
19\end{array}$ & $1,393,396,035$ & $1,349,675,833$ & $43,720,202$ & $30,868,006$ & $12,852,196$ & $0.92 \%$ & $2.22 \%$ \\
\hline Total & $17,572,884,863$ & $16,569,050,821$ & $1,003,834,042$ & $310,833,899$ & $693,000,143$ & $3.94 \%$ & $1.77 \%$ \\
\hline
\end{tabular}

Allowable rate of system loss is $2.22 \%$. System loss fluctuates and sometimes it goes beyond the allowable rate. Cost of system loss is shown in the Cost of sales in the income statement. The difference between the purchase and sale is the system loss. While gas is being transmitted to TGTDCL to GTCL system loss occurs because of leakage or lack of proper measurement channel. In the year 2018-2019 separately every month's system loss, purchase, sale, allowable amount and net system loss amount is shown. System loss fluctuates with the volume of purchase and sale of gas, consumption and wastage of gas.

Table 5: System loss in the cost of sales of financial year 2018-2019 


\begin{tabular}{|ll|}
\hline Total Cost of sales & $134,768,393,053$ \\
\hline Net Purchase Qty. in CM & $17,572,884,863$ \\
\hline Cost per CM & 7.67 \\
\hline System Loss Qty. in CM (after Allowable loss) & $693,000,143$ \\
\hline Cost of system loss in Taka (after Allowable loss) & $5,315,311,097$ \\
\hline Total margin loss against system loss & $173,250,036$ \\
\hline Total revenue loss against system loss & $5,488,561,133$ \\
\hline
\end{tabular}

The margin loss and revenue loss charged against system loss in financial year 2018-2019 income statement. The target is to lessen system loss to a tolerable level whereas allowable rate of system loss of TGTDCL is $2.00 \%$. After the prepaid metering system consumption has reduced so does revenue eventually the system loss has also decreased. It happened because system loss does not depend on the volume of gas sale rather it depends on the per unit of gas.

Table 6: Calculation of System Loss in 2019-2020 


\begin{tabular}{|c|c|c|c|c|c|c|c|}
\hline Month & $\begin{array}{l}\text { Net } \\
\text { Purchase }\end{array}$ & Sales & $\begin{array}{l}\text { Total } \\
\text { System } \\
\text { Loss }\end{array}$ & $\begin{array}{l}\text { Allowable } \\
\text { System } \\
\text { Loss }\end{array}$ & $\begin{array}{l}\text { Net } \\
\text { System } \\
\text { Loss }\end{array}$ & $\begin{array}{l}\text { System Loss } \\
\text { In \% }\end{array}$ & $\begin{array}{l}\text { Allowable } \\
\text { System } \\
\text { Loss \% }\end{array}$ \\
\hline Jul-19 & $1,415,913,308$ & $1,387,595,042$ & $28,318,266$ & $28,318,266$ & - & $0.00 \%$ & $2.00 \%$ \\
\hline $\begin{array}{l}\text { Aug- } \\
19\end{array}$ & $1,313,453,560$ & $1,287,184,489$ & $26,269,071$ & $26,269,071$ & - & $0.00 \%$ & $2.00 \%$ \\
\hline $\begin{array}{l}\text { Sep- } \\
19\end{array}$ & $1,401,575,445$ & $1,373,543,936$ & $28,031,509$ & $28,031,509$ & - & $0.00 \%$ & $2.00 \%$ \\
\hline Oct-19 & $1,358,379,004$ & $1,331,211,424$ & $27,167,580$ & $27,167,580$ & - & $0.00 \%$ & $2.00 \%$ \\
\hline $\begin{array}{l}\text { Nov- } \\
19\end{array}$ & $1,350,590,094$ & $1,323,578,292$ & $27,011,802$ & $27,011,802$ & - & $0.00 \%$ & $2.00 \%$ \\
\hline $\begin{array}{l}\text { Dec- } \\
19\end{array}$ & $1,325,273,197$ & $1,298,767,733$ & $26,505,464$ & $26,505,464$ & - & $0.00 \%$ & $2.00 \%$ \\
\hline $\begin{array}{l}\text { Jan- } \\
20\end{array}$ & $1,395,597,774$ & $1,367,685,819$ & $27,911,955$ & $27,911,955$ & - & $0.00 \%$ & $2.00 \%$ \\
\hline $\begin{array}{l}\text { Feb- } \\
20\end{array}$ & $1,350,279,288$ & $1,323,273,702$ & $27,005,586$ & $27,005,586$ & - & $0.00 \%$ & $2.00 \%$ \\
\hline $\begin{array}{l}\text { Mar- } \\
20\end{array}$ & $1,346,175,891$ & $1,319,252,373$ & $26,923,518$ & $26,923,518$ & - & $0.00 \%$ & $2.00 \%$ \\
\hline Apr-20 & $779,749,066$ & $764,154,085$ & $15,594,981$ & $15,594,981$ & - & $0.00 \%$ & $2.00 \%$ \\
\hline $\begin{array}{l}\text { May- } \\
20\end{array}$ & $1,153,600,608$ & $1,130,528,596$ & $23,072,012$ & $23,072,012$ & - & $0.00 \%$ & $2.00 \%$ \\
\hline $\begin{array}{l}\text { Jun- } \\
20\end{array}$ & $1,226,190,130$ & $1,201,666,327$ & $24,523,803$ & $24,523,803$ & - & $0.00 \%$ & $2.00 \%$ \\
\hline Total & $15,416,777,365$ & $15,108,441,818$ & $308,335,547$ & $308,335,547$ & - & $0.00 \%$ & $2.00 \%$ \\
\hline
\end{tabular}

Here, after installing prepaid meters in the financial year 2019-2020, the amount of total system loss and allowable system loss was the same. Thus, no system loss is measured. But there is still uncertainty because of the improper gas line, leakage in the pipeline and less metered intake point. The prepaid metering system has made no progress in recent years. GTCL supplies around 1500-1600 million mmcf of gas per day through the channels where there is no metered point. As a result, proper and accurate quantities cannot be measured. GTCL suggests installing a meter at every intake point.

Table 7: Revenue and Cost of Sales (BDT in Crore) 


\begin{tabular}{lll} 
Year & Revenue & Cost of sales \\
\hline $2014-15$ & $8,271.10$ & $7,092.01$ \\
\hline $2015-16$ & $11,379.98$ & $10,569.06$ \\
\hline $2016-17$ & $12,570.56$ & $11,844.73$ \\
\hline $2017-18$ & $14,216.06$ & $13,433.99$ \\
\hline $2018-19$ & $14,164.47$ & $13,462.02$ \\
\hline $2019-20$ & $16,987.94$ & $16,368.52$ \\
\hline
\end{tabular}

From table 5, it's quite clear that from year 2014-2018 revenue was high. Cost of sales were system loss was not included; revenue was higher. But after the installation of prepaid meter cost of sales got higher and revenue reduced. Though from all the years 2019's revenue is greater but it should be noted that cost had also increased. It is a result of reduced consumption and lesser wastage. Also, all these cannot be said with certainty.

\section{Discussions And Current Status}

There was no arrangement for measurement of gas consumption, such as a master meter, in the area before the prepaid meter implementation. Therefore, no concrete data was available regarding the gas consumption before metering. Thus, the savings of gas cannot be established with certainty; rather the analysis had to rely on assumed parameters.

After a few months into operation, a number of problems were found by a thorough inspection by TGTDCL representatives. Some randomly selected meters were sent to Institute of Information and Communication Technology (IICT), BUET, for further testing.

Their major findings were:

i. The calibration of the meters was not accurate.

ii. The quality of the materials used for electronic module was poor.

iii. Power supply system of the meter was of lower quality.

iv. LCD display was of poor quality.

Technical Faults The total number of faulty meters was 503 . Some meters had a single problem such as consumption error or battery damage etc., while others had multiple problems. Consumption error is defined as the difference between analogue and digital reading.

\section{Table 8: Technical faults found in the meters}




\begin{tabular}{|ll|}
\hline Technical Errors & Numbers \\
\hline Consumption Error & 375 \\
\hline Battery Damaged & 45 \\
\hline Meter Damaged & 18 \\
\hline Negative Digital Reading & 4 \\
\hline Display Damaged & 6 \\
\hline Meter Lock & 112 \\
\hline Card Charging in Meter & 178 \\
\hline Total fault count & 738 \\
\hline
\end{tabular}

It shows that consumption error is the highest among the different types of faults. About $44 \%$ of the meters were faulty in this regard. Significant number of meters also had card charging and meter lock problems. Irregular Activities A number of irregular activities were also detected in some meters Although the numbers are not very high, it is a matter of concern given the type of area where the project was implemented. It is likely that such activities would be more frequent in the less affluent areas of the city.

Financial Statement Revenues earned by selling gas through the pre-paid meters are compared to the equivalent flat rate earnings.

This paper made independent calculations based on the following main assumption:

1. Burners are kept full open for 6 hours and partially open for 4 hours.

2. Tariff rates are prevailing at the time of the project implementation.

3. Flat rate for a double burner stove is Taka $975 /$ month.

Due to the outbreak of Covid-19 the country is facing a breakdown in the prepaid meter installation. In the first six months of 2020 , exports have been dropped by $25.55 \%$ compared to the last six months of 2019 . Exports were dropped to just $\$ 520.01$ million in April 2020, which is the lowest in a decade and 80.97\% lower than the preceding month. In the first 11 months of 2020 , the total export value was $\$ 30,295.52$ million, $15.40 \%$ less than $\$ 35,812.27$ million in 2019 . Due to strict lockdown by the government, reduction in orders from developed countries, shipping restrictions, etc., negatively affected the country's exports. (Ahamed, 2021). Due to the restrictions, it is hard to procure required meters and install those. The current situation is not in favor of installing new pre-paid meters and the authority trying to formulate a policy to continue the project in the months ahead.

\section{Conclusion}

There was no foreknowledge of the gas consumption in the area where the prepaid meters were deployed. If some special arrangement, such as a master meter was installed on the supply main to the said area, a better indication of gas consumption before and after the project could be obtained. That would have helped to establish the amount of gas wasted or saved with more reliability. Some gas is also wasted through leaks, and during the process of lighting the burners. Moreover, $13 \%$ of the customers were offices and foreign citizens, whose gas usage should be quite different than regular domestic customers. It is easily understood that the usage trends between customers at different income levels would vary significantly. To address this problem, a comprehensive survey could be conducted to cover different types of neighborhoods. 
Reliable, accurate and durable meters are central to the success. It is also interesting to note that the revenue of the gas company actually reduced after the project. Perhaps that is an indication of reduced consumption and wastage, but it cannot be quantified with certainty. Reduction of revenue may act as a barrier for a gas company to invest in large scale metering projects, and prompt the company towards tariff hikes.

\section{References}

1. Ahmed, F. (2021). Corporate Boards, Audit Committees and Voluntary Disclosure: A Case Analysis on Bangladeshi Listed Companies. European Journal of Business and Management Research, 6(2), 153-155.

2. Ahamed, F. (2021). Impact of Public and Private Investments on Economic Growth of Developing Countries. arXiv preprint arXiv:2105.14199.

3. Alam, M. M., Khondker, R. K., \& Molla, M. S. (2013). Current Account Dynamics, Adjustment and Capital Mobility in Bangladesh. Global Disclosure of Economics and Business, 2(2), 117-126.

4. Alam, M. (2021). Output, Employment, and Price Effects of US Narrative Tax Changes: A Factor-Augmented Vector Autoregression Approach. arXiv preprint arXiv:2106.10844.

5. Alam, M. M. (2021). A Probit Estimation of Urban Bases of Environmental Awareness: Evidence from Sylhet City, Bangladesh. arXiv preprint arXiv:2107.08342.

6. Alam, M. M., \& Hossain, M. K. (2018). Policy Options on Sustainable Resource Utilization And Food Security In Haor Areas Of Bangladesh: A Theoretical Approach. International Journal of Social, Political and Economic Research, 5(1), 11-28.

7. Brkovic, M., Radovanovic, L., Desnica, E., Pekez, J., \& Adamovic, Z. (2015). Analysis of loss reduction in natural gas transportation and distribution. Energy Sources, Part B: Economics, Planning, and Policy, 10(2), 214-222.

8. Catherine, M., Sweet, S., \& Tim, J. (2009). A study of leakage from the UK natural gas distribution system. Energy Policy, Elsevier, 18(9), 809-818.

9. Ficco G, Dell'Isola M, Vigo P, et al. Uncertainty analysis of energy measurements in natural gas transmission networks. Flow Meas Instrum 2015; 42: 58-68.

10. Khan, M. F. H. (2021). Impact of Exchange Rate on Economic Growth of Bangladesh. European Journal of Business and Management Research, 6(3), 173-175.

11. Khan, T. H., Paul, T. K., Shahabuddin, G. M., Wahid, K., Chowdhury, A. H., \& Kabir, S. M. L. (2009, December). Towards design of a smart prepaid gas metering system. In 2009 International Conference on Innovations in Information Technology (IIT) (pp. 55-59). IEEE.

12. Khan, M. F., Zoha, A., \& Ali, R. L. (2007, July). Design and implementation of smart billing and automated meter reading system for utility gas. In 2007 International Conference on Information and Emerging Technologies (pp. 1-6). IEEE.

13. Khan, M. F., Zoha, A., \& Ali, R. L. (2012). Design and Implementation of Smart Billing and Automated Meter Reading System for Utility Gas. COMSATS.

14. Mahmoudi, M. (2021). Identifying the Main Factors of Iran's Economic Growth Using Growth Accounting Framework. European Journal of Business and Management Research, 6(5), 239-245. https://doi.org/10.24018/ejbmr.2021.6.5.1099

15. Minar, S. J. (2019). Tatmadaw's Crackdown on The Rohingyas: A SWOT Analysis. Journal of Social Studies, 5(1), 1-5.

16. Minar, S. J. (2018). Grand Strategy and Foreign Policy: How Grand Strategy Can Aid Bangladesh's Foreign Policy Rethinking?. Journal of Social Studies, 4(1), 20-27.

17. Minar, S. J \& Abdul, H. (2020). The Rohingyas of Rakhine State: Social Evolution and History in the Light of Ethnic Nationalism. Social Evolution \& History, 19(2), 115-144

18. Mohammad, M. A., \& Mohammad, R. I. (2010). Revisiting the Feldstein-Horioka Hypothesis of savings, investment and capital mobility: evidence from 27 EU countries.

19. Pramanik, P. (2020, December). Optimization of market stochastic dynamics. In SN Operations Research Forum (Vol. 1, No. 4, pp. 1-17). Springer International Publishing. 
20. Pramanik, P., \& Polansky, A. M. (2020). Optimization of a Dynamic Profit Function using Euclidean Path Integral. arXiv preprint arXiv:2002.09394.

21. Pramanik, P., \& Polansky, A. M. (2021). Optimal Estimation of Brownian Penalized Regression Coefficients. arXiv preprint arXiv:2107.02291.

22. Pramanik, P. (2021). Effects of water currents on fish migration through a Feynman-type path integral approach under [Formula: see text] Liouville-like quantum gravity surfaces. Theory in Biosciences= Theorie in den Biowissenschaften.

23. Titas, BD. (2019). Annual Report-TGTDCL-2018-19 (AGM Report). Dhaka, Dhaka: Titas Gas.

24. Titas, BD. (2020). Annual Report-TGTDCL-2019-20 (AGM Report). Dhaka, Dhaka: Titas Gas.

25. Salma, U. (2021). Macroeconomic Determinants of Inflation in Bangladesh. European Journal of Business and Management Research, 6(5), 264-267.

26. Ying, X., Wang, X., \& Mai, F. (2019). Calculation of theoretical transmission loss in trunk gas pipeline. Advances in Mechanical Engineering, 11(12), 1-12. 